\section{Combined Spinal Epidural Anesthesia during Colon Surgery in a High-Risk Patient. Case Report}

Luiz Eduardo Imbelloni, TSA, M.D., Marcos Fornasari, M.D., José Carlos Fialho, M.D.

\section{INTRODUCTION}

Combined spinal epidural anesthesia (CSEA) has advantages over single injection epidural or subarachnoid blockades. Soresi was the first to report this technique ${ }^{1}$. Segmental subarachnoid block in the lower thoracic region was performed in 1954 in 10 adult patients by the subarach- noid deposit of $0.5 \mathrm{~mL}$ of $5 \%$ procaine $(25 \mathrm{mg})$ in the intervertebral space of the $12^{\text {th }}$ thoracic vertebra ${ }^{2}$. The pattern of the sensorial segmental blockade and the concentration of procaine, especially around the posterior roots (sensorial) provided anesthesia without systemic repercussions. A preliminary study showed that segmental subarachnoid block can be an effective technique in videolaparoscopic cholecystectomy in high-risk patients ${ }^{3}$. General anesthesia with opioids and neuromuscular blockers, as well as mechanical ventilation, interferes with the respiratory system. The incidence of bronchial hyperactivity is elevated in patients with asthma or chronic obstructive pulmonary disease (COPD), and regional blocks are frequently used to avoid the intubation stimulus. The objective of this report was to present a case in which segmental block with CSEB can be effective in gastrointestinal surgeries with spontaneous respiration.

\section{CASE REPORT}

This is a 71-year old female, $60 \mathrm{~kg}, 162 \mathrm{~cm}$, ASA III, with diabetes type II, hypertension, and COPD admitted for resection of a right colon tumor; erythrocytes $4,780,000 / \mathrm{mm}^{3}$, hemoglobin 12.2 g.dL ${ }^{-1}$, hematocrit $38.4 \%$, platelets $160,000 / \mathrm{mm}^{3}$, prothrombin time $14.3 \mathrm{sec}$, PTT $74 \%$, and INR 1.22. Ventricular premature complexes were seen on the ECG. The patient was being treated with $10 \mathrm{mg}$ of losartan a day, $100 \mu \mathrm{g}$ of levothyroxine sodium a day, $30 \mathrm{mg}$ of dilfazem $\mathrm{mg}$ and $2 \mathrm{mg}$ of clonazepam a day. She also had diet-controlled diabetes. An $18 \mathrm{G}$ catheter was used for venoclysis and $500 \mathrm{~mL}$ of Ringer's lactate, $50 \mathrm{mg}$ of ranitidine, $40 \mathrm{mg}$ of omeprazole, $10 \mathrm{mg}$ of dexamethasone, $8 \mathrm{mg}$ of ondansetron, and $10 \mathrm{mg}$ of metochlopramide were administered. After sedation with $75 \mu \mathrm{g}$ of fentanyl and $1 \mathrm{mg}$ of midazolam, CSEA was performed in the $T_{4}-T_{5}$ space with a set of needle-throughneedle (BBraun, Melsungen, AG) and after observing the return of CSF $8 \mathrm{mg}$ of $0.5 \%$ isobaric bupivacaine and $50 \mu \mathrm{g}$ of morphine were administered, and a 20G catheter was inserted in the epidural space. After five minutes, sensorial blockade extended from $T_{3}$ to $L_{5}$ with a $2^{\text {nd }}$ degree motor blockade. Blood pressure decreased from $118 \times 74$ to $99 \times$ $68 \mathrm{mmHg}$ and the heart rate (HR) from 90 to 78 beats per minute without nausea or vomiting. The patient remained hemodynamically stable without the need of vasopressors or atropine.

During the procedure oxygen 3 L. min $^{-1}$ was administered via a Hudson mask. Reduction in oxygen saturation or any degree of respiratory difficulty was not observed. The collector of the capnograph was connected to the nose of the patient, showing the curve and $\mathrm{P}_{\mathrm{ET}} \mathrm{CO}_{2}$ during the procedure. During the surgery $1,600 \mathrm{~mL}$ of $\mathrm{NS}, 500 \mathrm{~mL}$ of $6 \%$ hetastarch, and $400 \mathrm{~mL}$ of fresh frozen plasma were administered.

The surgery lasted three hours and $25 \mathrm{mg}$ of $0.5 \%$ bupivacaine were administered through the epidural catheter two hours after the subarachnoid injection. Sedation was achieved with fractionated doses of midazolam (total of $6 \mathrm{mg}$ ). A 
nasogastric tube was not used. At the end of the surgery, 40 $\mathrm{mg}$ of tenoxicam and $3 \mathrm{~g}$ of dypirone were administered, and the epidural catheter was left in place for further administration of morphine. The patient was transferred to the ICU without motor blockade.

\section{DISCUSSION}

This case report demonstrates that CSEA with low doses of isobaric bupivacaine and mid-thoracic puncture can be used for segmental spinal block $\left(T_{3}\right.$ and $\left.L_{5}\right)$ in a patient with chronic obstructive pulmonary disease undergoing surgical resection of a colon tumor without tracheal intubation.

Magnetic resonance imaging (MRI) evaluation of the distance between the dura mater and the spinal cord in the thoracic region in 16 patients demonstrated mean values of $4.22 \mathrm{~mm}$ at the level of $\mathrm{T}_{2}, 5.29 \mathrm{~mm}$ in $\mathrm{T}_{5}$, and $4.08 \mathrm{~mm}$ in $\mathrm{T}_{10}{ }^{4}$. Judicious use of subarachnoid injections in thoracic segments can be as much an option as epidural injections for the experienced anesthesiologist. Unlike other investigators ${ }^{3}$ who used pencil-point needle, cut-bevel needle was used in this case due to its terminal orifice. The orifice of the penciltip needle is located $0.8 \mathrm{~mm}$ before the tip of the needle, requiring it to be introduced almost $2 \mathrm{~mm}$ into the subarachnoid space to make sure the orifice is inside the canal and to observe the return of $\mathrm{CSF}^{5}$. It is true that the nontraumatic needle has at least $1 \mathrm{~mm}$ of blind tip beyond the orifice, and there is a tendency to advance the needle into the subarachnoid space more than it is necessary than with the cut-bevel needle which, after crossing the dura mater, allows immediate backflow of CSF. Thus, needle insertion is safer and it does not damage the spinal cord. Similarly, the entrance angle between $\mathrm{T}_{5}-\mathrm{T}_{6}$ (almost $60^{\circ}$ ) increases the distance of the tip of the needle from the posterior surface of the spinal cord measured by MRI, making it safer.

Resection of colon tumors is routinely done under general anesthesia with tracheal intubation. Studying the pulmonary function of COPD patients undergoing surgeries for carcinoma or mammaplasty under segmental thoracic epidural block, only a small reduction in forced expiratory volume in one second without increasing the degree of airways obstruction was observed ${ }^{6}$, thus leading to the conclusion that regional block can be a good alternative to general anesthesia. General anesthesia with or without neuromuscular blockade leads to a reduction in residual functional capacity. Residual neuromuscular blockade is a predictor of postoperative pulmonary complication, causing alveolar hypoventilation and gastric regurgitation with consequent bronchoaspiration ${ }^{7}$. The routine use of nasogastric drainage accelerates recovery of the bowel function, but it can increase the risk of silent bronchoaspiration ${ }^{8}$. By choosing regional blocks, one avoids manipulation of the airways, residual neuromuscular blockade, and the use of gastric drainage. On a recent review of the perioperative management of COPD patients, the authors ${ }^{8}$ concluded that whenever possible neuro axis block, peripheral nerve block, or general anesthesia without intubation are indicated. Thus, considering that regional block is considered the preferred technique in COPD patients, we favored CSEA injecting small doses of local anesthetic in the subarachnoid space, and inserting the catheter in the epidural space for further administration if necessary. The use of low doses and thoracic puncture allows the segmentation of the spinal block observed by several authors ${ }^{2,3}$ that in this case remained between $\mathrm{T}_{3}$ and $\mathrm{L}_{5}$ with incomplete motor blockade.

Typical cardiovascular effects of spinal block include a reduction in blood pressure and venous pressure with only a mild reduction in heart rate, ejection fraction, or cardiac output even in patients with poor left ventricular function. Hypotension develops due to a reduction in systemic vascular resistance and central venous pressure secondary to the sympathetic blockade, with vasodilation and redistribution of central blood volume to the extremities and splanchnic vascular bed ${ }^{9}$. This sympathetic blockade is rarely complete and some preservation of the sympathetic reflex for challenge situations is observed ${ }^{10}$. Hypotension and bradycardia were not observed during the procedure. Oxygen saturation as well as $\mathrm{P}_{\mathrm{ET}} \mathrm{CO}_{2}$ remained within normal limits during the procedure demonstrating that high spinal block can be safe, even in the absence of tracheal intubation.

Compared to spinal block, CSEA offers flexibility, since the duration of the anesthesia can be extended by using an epidural catheter. This was demonstrated by the injection of bupivacaine through the catheter approximately two hours after the beginning of the surgery. Combined spinal epidural anesthesia also allows a reduction in the duration of the anesthesia by the subarachnoid administration of the minimal dose of the local anesthetic to establish the initial level for the surgery. In the present case, an initial dose of only 8 $\mathrm{mg}$ of isobaric bupivacaine was used, i.e., almost half of the dose used in another case report with lumbar puncture ${ }^{11}$.

Patients with severe pulmonary disease have a high risk of postoperative complications when undergoing general anesthesia. Several cases of colorectal surgeries with neuro axis block without general anesthesia or tracheal intubation have been described in the literature. This case demonstrated that segmental spinal block using CESA in COPD patients can be an effective technique for colorectal surgery without the need to manage the upper airways.

\section{REFERÊNCIAS - REFERENCES}

01. Soresi AL - Episubdural anesthesia. Anesth Analg, 1937:16:306310.

02. Frumin MJ, Schwartz $\mathrm{H}$, Burns $\mathrm{J}$ et al. - Dorsal root ganglion blockade during threshold segmental spinal anesthesia in man. J Pharm Exp Ther, 1954;112:387-392.

03. van Zundert AAJ, Stultiens G, Jakimowicz JJ et al. - Laparoscopic cholecystectomy under segmental thoracic spinal anaesthesia: a feasibility study. Br J Anaesth, 2007;98:682-686. 
04. Imbelloni LE, Ferraz Filho JR, Quirici MB et al. - Magnetic resonance imaging of the spine column. $\mathrm{Br} \mathrm{J}$ Anaesth, 2008; 101:433-434.

05. Krommendijk EJ, Verheinjen R, van Dijk B et al. - The PENCAN 25gauge needle: a new pencil-point for spinal anesthesia tested in 1,193 patients. Reg Anesth Pain Med, 1999:24:43-50.

06. Groeben H, Schäfer B, Pavlakovic G et al. - Lung function under high thoracic segmental epidural anesthesia with ropivacaine or bupivacaine in patients with severe obstructive pulmonary disease undergoing breast surgery. Anesthesiology, 2002;93: 536-541.

07. Eikermann M, Blobner M, Groeben $\mathrm{H}$ et al. - Postoperative upper airway obstruction after recovery of the train of four ratio of the adductor pollicis muscle from neuromuscular blockade. Anesth Analg, 2006;102:937-942.

08. Licker M, Schweizer A, Ellenberger C et al. - Perioperative medical management of patients with COPD. Int $\mathrm{J}$ Chron Pulmon Dis, 2007;2:493-515.

09. Butterworth J - Physiology of spinal anesthesia: what are the implications for management? Reg Anesth Pain Med, 1998;23:370373; discussion 384-387.

10. Stevens RA, Frey K, Liu SS et al. - Sympathetic block during spinal anesthesia in volunteers using lidocaine, tetracaine, and bupivacaine. Reg Anesth, 1997;22:325-331.

11. Kapala M, Meterissian S, Schricker T - Neuraxial anesthesia and intraoperative bilevel positive airway pressure in a patient with severe chronic obstructive pulmonary disease and obstructive sleep apnea undergoing elective sigmoid resection. Reg Anesth Pain Med 2009;34:69-71.

\section{RESUMEN}

Imbelloni LE, Fornasari M, Fialho JC - Uso del Bloqueo Combinado Raquiepidural durante Cirugía de Colon en Paciente de Alto Riesgo. Relato de Caso.

JUSTIFICATIVA Y OBJETIVOS: El bloqueo combinado raquiepidural (BCRE), tiene ventajas sobre la anestesia epidural o subaracnoidea con inyección única. El objetivo de este relato, fue presentar un caso donde la anestesia subaracnoidea segmentaria, puede ser una técnica efectiva para la intervención quirúrgica gastrointestinal con respiración espontánea.

RELATO DEL CASO: Paciente estado físico ASA III, diabetes mellitus tipo II, con hipertensión arterial sistémica y enfermedad pulmonar obstructiva crónica, que fue indicada para la resección del tumor de colon derecho. El BCRE se realizó en el interespacio $T_{5}-T_{6}$, y se inyectaron $8 \mathrm{mg}$ de bupivacaína a 0,5\% isobárica con 50 ug más de morfina en el espacio subaracnoideo. El catéter epidural (20G) fue introducido cuatro centímetros en dirección cefálica. La sedación se obtuvo con dosis fraccionadas de $1 \mathrm{mg}$ de midazolam (total de $6 \mathrm{mg}$ ). La bupivacaína a 0,5\% se administró en bolo de $25 \mathrm{mg}$ a través del catéter dos horas después de la anestesia subaracnoidea. No hubo necesidad de aplicar vasopresor ni atropina.

CONCLUSIONES: Este caso nos demuestra que la raquianestesia segmentaria puede ser una técnica anestésica para la operación gastrointestinal con respiración espontánea. 